
FOR WALL CLAY OF A REGION

\section{浦 憲親} $* 1$

山本智大 $* 2$

キーワード

壁土，地域，実施調合，粒子径，強さ，日干しレンガ

Keywords:

Wall clay, Region, Trial mixing, Particle size, Strength, Sun-dried brick
Norichika URA —— $* 1 \quad$ Tomohiro YAMAMOTO — $* 2$

In this paper, properties of the original soil for wall clay are described. The properties of wall clay change with region, $\mathrm{S}$ (:sand)/C(:soil), mizuawase, etc. Results are as follows; 1) Property of the wall clay is stabilized by constant consistency. 2) With regard to bending, compressive, shear and tensile strength, $\mathrm{S} / \mathrm{C} 0 \%>\mathrm{S} / \mathrm{C} 85 \%$, and trial mixing $>$ basic mixing. 3) For your reference, the compressive strength of the sun-dried brick is $2.0 \mathrm{~N} / \mathrm{mm}^{2}$.

\section{1.はじめに}

土壁は、土自体が無尽蔵で地域を問わず入手できるため多くの 建物、土塀等にも利用されてきた。しかし、最近の風潮は拙速な ことを評価することから、荒壁、中塗り仕上げまでを含め、乾燥 に時間を要する土壁は敬遠され、戸建住宅ではほとんど見ること がない状況である。一方では廃棄物処理、吸放湿性および耐火性 などに加えて再利用できる点から資源循環材料として改めて見直 されている。また、土壁は、地域によって小舞間隔も異なること から、鈴木ら ${ }^{9)}$ は実大供試体による力学的解析を試みている。し かし、構造解析の多くは塗り方および小舞材料など地域の工法に ついて評価するが原土そのものを調べることは少ない。

壁土用原土について、岩崎ら ${ }^{1)}$ は福島産土を主に、土壁の調合 から土の化学分析を行っている。與石ら 2）3）は荒壁および中塗 り土として必要な品質条件の検討を行い、土蔵に用いられた壁土 の材料特性も調べている。中尾ら ${ }^{4)}$ は中塗り土の強度等の相互関 係を、三芳ら ${ }^{6)}$ ８) は熊本産土を基準に京都および埼玉産土の強 さを、山田ら ${ }^{5)}$ は壁土の定温乾燥機による促進乾燥と強さについ て検討している。しかし、いずれも一定のコンシステンシーの元 で壁土用原土の性質を調べたものは少なく、多くは左官業から提 供されたものである。その背景にあるのは、土壁の実大実験が主 になるため原土の性質よりも、左官職人の塗り方等の影響が大き いこともある。

本報告は、無限にある壁土の全てを調べることは無意味で現実 的でないことから、実際に使われ採取地の分かる地域産の壁土用 原土を簡易な方法で評価することを目的に実験的に調べている。 しかしながら、土壁は施工方法、原土の地域性、左官職人の技術 差もあることから、定量化は困難と言える。したがって、一定調 合の元で原土の性質を評価することで既存建物の土壁の安全、あ るいは安心が確認できれば新たな工法・構法への発展と改善に繋
がり、一つの指標になると考える。土壁の評価は、戸建住宅への 普及による新しい街並や町屋 18) 19) の維持保全が期待できるとと もに、環境改善、護美の出ない 21 世紀の建築材料の方向性を示唆 するものと言える。

\section{2.入手した壁土用原土（図1)}

図 1 に、地域産で入手した壁土用原土の位置を示す。

図中の○は、壁土用原土を採取している場所から得たものであ る。 $\triangle$ は、建材商社、設計事務所および住宅・建設業を通して電 話等で入手を試みたものである。しかし、いずれの場合も壁土は 入手できるが、その採取場所は不明との回答が得られた。本研究 では現地採取、あるいは採取場所の明らかなことを原則にしてい ることから試料数は少ない。

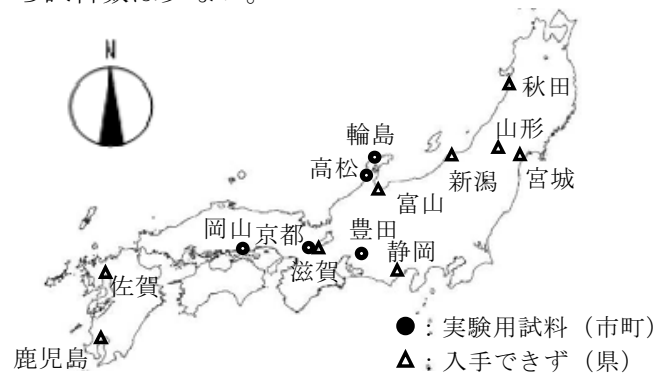

図 1 入手した壁土用原土の採取地（地域産）

\section{3. 実験研究の方法}

本研究の方法および実験手順は以下の通りで、採取地の明らか な 5 つの原土を用いた壁土の基礎的性質を調べている。

1 ）基本調合 ${ }^{10)}$ による壁土評価

2 ）実施調合による壁土評価

実験は 1 ）の場合、表 1 の基本調合を適用 10) 11) し、2）はコ ンシステンシーが一定になるよう実験 1 ）について試し練りで調

\footnotetext{
金沢工業大学環境・建築学部建築系

(テ 921-8501 石川県石川郡野々市町扇が丘 7-1)

(株大川原製作所（静岡）
}

\footnotetext{
I Dept. of Architecture, College of Environmental Engineering and Architecture, Kanazawa Institute of Technology, Ph. D.

OKAWARA CORPORATION (Shizuoka)
} 
合補正したものである。

\section{4. 基本調合および実施調合による壁土評価}

\section{1 使用材料（写真 1 )}

実験用原土は、地域産の輪島（土蔵用）、高松（土蔵および住 宅用)、岡山（荒壁および中塗り用）および豊田産土（中塗り用） の 6 種と、従来から基準にしている荒壁および中塗り兼用の京都 産土を用いた。京都産は $18 \mathrm{~kg}$ 前後の袋詰で市販され供給が安定し ていることから原土を評価する際の比較基準にしている。

地域産の試料は、中塗り土を除いて搬入後 $2.5 \mathrm{~mm}$ ふるいにかけ 通過したものを使用した。また、岡山（中塗り用）および豊田産 土の場合、前者は搬入前に $2.5 \mathrm{~mm}$ ふるいにかけたもので、後者は 水通しを行っている。練混ぜ水は大学内の飲料用井戸水、砂は手 取川産の川砂 $(2.5 \mathrm{~mm})$ を表乾状態で用いた。スサは荒壁土の場合、 長さ不揃いの市販の稲ワラスサ、中塗り土はモミスサを使用した。

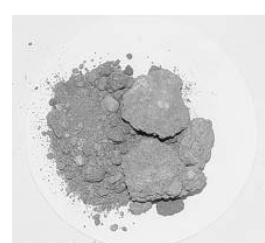

輪島産土（土蔵用）

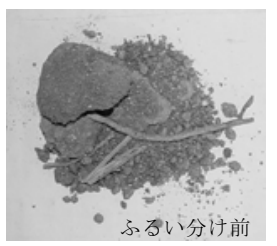

岡山産土（荒壁用）

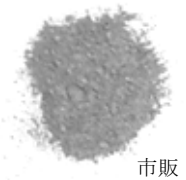

京都産土

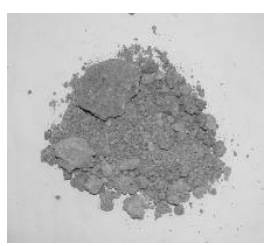

高松産土（土蔵用）

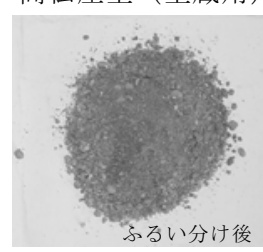

岡山産土 (中塗り用)

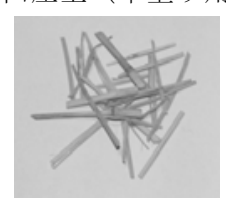

稲ワラスサ
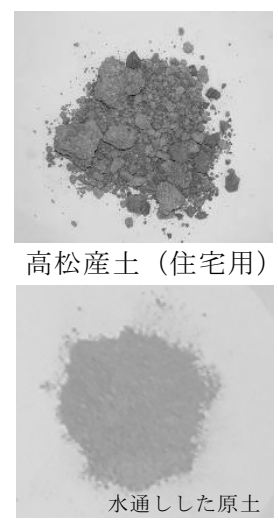

写真 1 原土の搬入時の状況およびスサの形状

\section{2 基本調合（表 1)}

4. 2. 1 基本調合による壁土（実験 1)

実験 1 ）は、原土に関わらず表 1 京都産土の基本調合を用いた が、含水率は考慮していない。壁土は多くの場合、量の多少はあ るが現場ではほとんどが砂（S）を加えることから、原土（C）と の割合を砂原土比 $(\mathrm{S} / \mathrm{C})$ としている。

荒壁土は S/C 0 および $85 \%$ の輪島、高松（土蔵および住宅用）、 岡山（荒壁用）および京都産土の 5 種、中塗り土は S/C 85\%で前 述の岡山（荒壁用）を除く 4 種の他に岡山（中塗り用）および豊 田産土を含めた 6 種で、それぞれフロー值を測定した。尚、強さ 試験用供試体は、荒壁および中塗り土の水合せ 0 日の夕作製し、 前者については一部で水合せ 7 日も調べている。

\section{2 . 2 実施調合による壁土（実験 2)}

実験 2 ）は、実験 1 ) で目標フロー值 $135 \pm 10$ を満足しない壁 土について補正を行っている。フロー值については決め方等の詳 細を文献 10) に示す。

調合はスサ（St）量を一定とし、水（W）の量を変えることに
より原土および砂を増減させ、フロー值が得られるまで補正を繰 り返した。供試体は、荒壁土の S/C 0（5 種）および 85\%（5 種） で水合せ 0 日のみ作製した。

$$
\mathrm{C}+\mathrm{S}+\mathrm{W}+\mathrm{S} \mathrm{t}=1000(\mathrm{~m} \ell)
$$

ここに、C：原土 (2.65)、 $\mathrm{S}$ : 砂 (2.56)、W : 練混ぜ水 $(1.0)$ 、 $\mathrm{S} \mathrm{t}$ ：スサ $(0.2) \quad()$ : 密度 $\left[\mathrm{g} / \mathrm{cm}^{3}\right]$

表 1 基本調合

\begin{tabular}{|c|c|c|c|c|c|c|c|}
\hline \multirow[b]{2}{*}{$\begin{array}{c}\text { 原土 } \\
\text { (地域産) }\end{array}$} & \multirow[b]{2}{*}{ 塗り層 } & \multirow{2}{*}{$\begin{array}{l}\text { 砂原 } \\
\text { 土比 } \\
\mathrm{S} / \mathrm{C} \\
(\%) \\
\end{array}$} & \multicolumn{4}{|c|}{$(g / \ell)$} & \multirow[b]{2}{*}{ 備考 } \\
\hline & & & $\begin{array}{l}\text { 原土 } \\
\text { (C) }\end{array}$ & $\begin{array}{l}\text { 砂 } \\
\text { (S) }\end{array}$ & $\begin{array}{l}\text { 水 } \\
\text { (W) }\end{array}$ & $\begin{array}{l}\text { スサ } \\
(\mathrm{St})\end{array}$ & \\
\hline \multirow{3}{*}{ 京都産土 } & \multirow{2}{*}{ 荒壁 } & 0 & 1096.1 & 0 & 449.4 & 27.4 & \multirow{3}{*}{$\begin{array}{c}\text { 実験 } 1 \text { ) } \\
\text { の調合 } \\
\text { (基本調合) }\end{array}$} \\
\hline & & 85 & 710.1 & 603.6 & 394.8 & 20.3 & \\
\hline & 中塗り & 85 & 710.1 & 603.6 & 394.8 & 20.3 & \\
\hline \multirow{2}{*}{$\begin{array}{l}\text { 輪島産土 } \\
\text { (土蔵用) }\end{array}$} & \multirow{2}{*}{ 荒壁 } & 0 & 947.7 & 0 & 505.4 & 27.4 & \multirow{10}{*}{$\begin{array}{c}\text { 実験 } 2 \text { ) } \\
\text { の調合 } \\
\text { (実施調合) }\end{array}$} \\
\hline & & 85 & 659.3 & 560.4 & 430.8 & 20.3 & \\
\hline \multirow{2}{*}{$\begin{array}{l}\text { 高松産土 } \\
\text { (土蔵用) }\end{array}$} & \multirow{2}{*}{ 荒壁 } & 0 & 960.9 & 0 & 500.4 & 27.4 & \\
\hline & & 85 & 701.6 & 596.4 & 400.8 & 20.3 & \\
\hline \multirow{2}{*}{$\begin{array}{l}\text { 高松産土 } \\
\text { (住宅用) }\end{array}$} & \multirow{2}{*}{ 荒壁 } & 0 & 1000.7 & 0 & 485.4 & 27.4 & \\
\hline & & 85 & 701.6 & 596.4 & 400.8 & 20.3 & \\
\hline \multirow{2}{*}{$\begin{array}{l}\text { 岡山産土 } \\
\text { (荒壁用) }\end{array}$} & \multirow{2}{*}{ 荒壁 } & 0 & 1096.1 & 0 & 449.4 & 27.4 & \\
\hline & & 85 & 710.1 & 603.6 & 394.8 & 20.3 & \\
\hline $\begin{array}{l}\text { 岡山産土 } \\
\text { (中塗り用) }\end{array}$ & 中塗り & 85 & 710.1 & 603.6 & 394.8 & 20.3 & \\
\hline $\begin{array}{c}\text { 豊田 } \\
\text { (中塗り用) }\end{array}$ & 中塗り & 85 & 710.1 & 603.6 & 394.8 & 20.3 & \\
\hline
\end{tabular}

\section{3 供試体の作製}

供試体は、JIS R 5201-1992（セメントの物理試験方法）に従 い三連型枠 $\left(\square 40 \times 40 \times 160 \mathrm{~mm}: 256 \mathrm{~cm}^{3}\right.$ 。以後、ようかんと称す $)$ を用い試料を 2 層に分け、モルタル供試体作製用の突き棒 $(\square 35 \times 35 \mathrm{~mm})$ で各層 20 回ずつ突いた後、表面をコテでならし作 製した。詳細は文献 10）に示す。

養生は、実験室内で気中養生（室温：15 $30^{\circ} \mathrm{C}$ 、湿度 : 平均 $60 \%$ R. H. ) とし、脱型は供試体作製後 3 日目に側面、7 日目に完全脱 型を目安にしているが、岡山産土のみ乾きが遅く 10 日目に完全脱 型を行った。

\section{4 実験方法（図 2 図 5, 写真 2 写真 3)}

原土の含水率は、JIS A 1125-2009（骨材の含水率試験法およ び含水率に基づく表面水率の試験法）に従い、次式により求め 3 試料の平均值とした。

$$
\begin{aligned}
\mathrm{w}=\left\{\left(\mathrm{m}_{1}-\mathrm{m}_{2}\right) / \mathrm{m}_{2}\right\} \times 100 \\
\text { ここに、 } \mathrm{w} \quad \text { : 含水率 }(\%) 、 \mathrm{~m}_{1}: \text { 乾燥前の質量 }(\mathrm{g}) 、 \\
\mathrm{~m}_{2} \text { : 乾燥後の質量 }(\mathrm{g})
\end{aligned}
$$

土のふるい分け試験 JIS A 1204-2009（土の粒度試験方法）で は、手ふるいの場合ふるい目 $0.075 \mathrm{~mm}(75 \mu \mathrm{m})$ 程度が限界で、それ 以下は沈降分析よるが 2 0. 020m (2000 20 $\mu \mathrm{m})$ まで手ふるいし た。沈降分析は試薬として劇薬の過酸化水素、分散剤のへキサメ タりん酸ナトリウムなど安全性の確保や管理の点で問題もあり、 レーザー回折式粒度分布測定装置 (SALD-3000S) を用いて $2.5 \mathrm{~mm}$ るいを通過した試料について測定值が安定するまで繰り返し調べ た。レーザー回折による粒度分布の積算值（\%）は手ふるいの粒 径加積曲線と平行し、粒径 $1 \mu \mathrm{m}$ 以下まで広範囲に測定できる。ま た、積算值は粒径加積曲線の通過質量百分率（\%) と一致するこ 
とから、手ふるいの通過質量百分率と看做した。

吸放湿試験は、JIS A 1470-1-2009（建築材料の吸放湿性試験 方法）に準じて行った。吸湿および放湿はそれぞれ 48 および 72 時間とした。供試体はようかんを使用し、他に能登半島地震 (2007 年 3 月 25 日) で被害を受けた土蔵の部分補修に用いている輪島産 土で作製の日干しレンガ $(\square 210 \times 150 \times 70 \mathrm{~mm}: 2200 \mathrm{~cm}$, 密度 : $1.24 \mathrm{~g} / \mathrm{cm}^{3}$, 含水率：5.9\%）12）17) についても調べている。製造法 は文献 12)に示すが、調合等は明確でなく小学生が夏休み中に製 造したものもある。このような製造方法は、若年労働力、人手不 足の地域の補修程度であれば現実的な方法で調合を云云すること 自体が本末転倒であるが、強さを明らかにしておくことは土を主 材にした工法・構法の普及の一つになると考える。

ようかんの曲げおよび圧縮強さ試験は、一軸圧縮試験装置を用 い載荷速度 $2 \mathrm{~mm} / \mathrm{min}$ で、最大荷重から $20 \%$ 減少もしくは目視で破 壊が確認された場合に終了した。また、試案として二面せん断お よび引張強さ試験を行った 10）13)。土塗り小舞壁では、水平力を受 けた場合、荷重の小さい変形初期では壁土が抵抗するためせん断 の評価が求められる。また、変形が大きくなると小舞を挟みスサ が反対側に出るなど土との付着を明らかにするためにも引張試験 の検討が必要と考える。日干しレンガは JIS R 1250-2009（普通 れんが）に従い、加圧面を石膏でキャッピングした後、圧縮強さ 試験を行っている。

\section{5 実験結果および考察}

\section{1）原土の搬入時の状況（写真 1)}

搬入時の輪島、高松（土蔵および住宅用）および岡山産土（荒 壁用）は、いずれもこぶし大の固まり、木根などを含んでいる。 京都産土は袋詰めで市販されているが、袋によって土の色が異な るように基本調合でも目標フロー值よりずれることがある。

輪島産土は粘りがあり、赤みがかった茶色で、しつとりしてい る。一方、高松産土の土蔵および住宅用原土は、明るい茶色で両 者に見た目の差異はないが、握ると前者は後者より粘りがある。

岡山産土（荒壁および中塗り用）は色についてみると高松産土 と大差ないが、しっとりさ、粘りがなく砂のようにザラザラした 感触を得る。豊田産土は水通ししているが、黄色に近い茶色で、 粘りは輪島および高松産土に比べると少ないが、微粒分も多く岡 山産土と同様に満遍なく分布していることが図 7 からも示される。

\section{2 ）原土の含水率および調合（表 2 、図 6 ）}

原土の含水率は、実験室で 1 力月ほど寝かしたものを調べたが、 豊田産土を除いて大略 9〜10\%で大差ない。したがって、実施調 合においても含水率による補正をしていない。

調合では、原土の種類に関係なく砂原土比（S/C）の増加に伴 い単位水量は減少する。荒壁土の単位水量は S/Cによって異なる が、原土の含水率と単位水量の関係 (実験 2 ) は相関係数 $r=-0.5$ 以上で、粒径幅の広い原土ほど少なくなる。したがって、京都、 岡山は少ないが、輪島、高松（土蔵および住宅用）は多くなる。

表 2 原土の含水率

\begin{tabular}{|c|c|c|c|c|c|c|c|}
\hline \multirow{2}{*}{ 種類 } & \multirow{2}{*}{ 京都産土 } & \multirow{2}{*}{ 輪島産土 } & \multicolumn{2}{|c|}{ 高松産土 } & \multicolumn{2}{|c|}{ 岡山産土 } & \multirow{2}{*}{ 豊田産土 } \\
\hline & & & 土蔵用 & 住宅用 & 荒壁用 & 中塗り用 & \\
\hline $\begin{array}{c}\text { 含水率 } \\
(\%)\end{array}$ & 9.66 & 9.13 & 9.40 & 10.2 & 10.6 & 9.52 & 2.83 \\
\hline
\end{tabular}

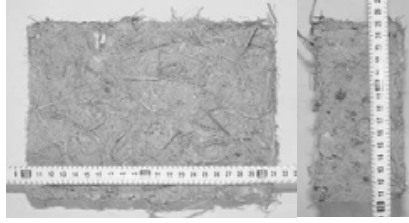

$\square 210 \times 150 \times 70$ （吸放湿試験用：実寸）

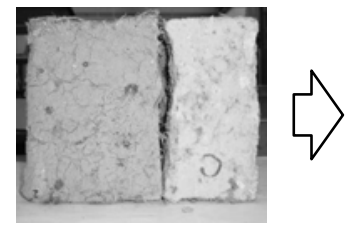

載荷面の凹み（試験前）

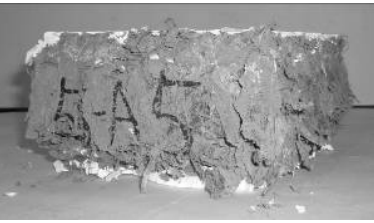

圧縮試験（破壊後） $\square 150 \times 100 \times 70 （ J I S$ R 1250-2009、強さ試験用：半切）

写真 2 輪島産土を用いた補修用の日干しレンガ（萩野氏提供） ${ }^{12}$

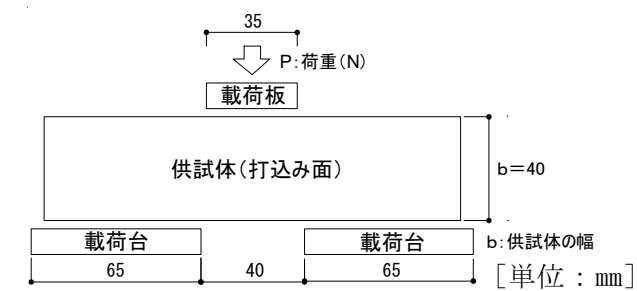

図 2 せん断強さ試験方法 10

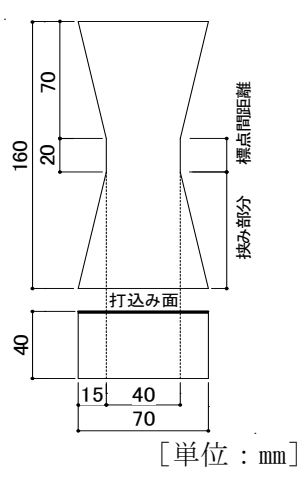

図 3 壁土引張供試体 ${ }^{13}$

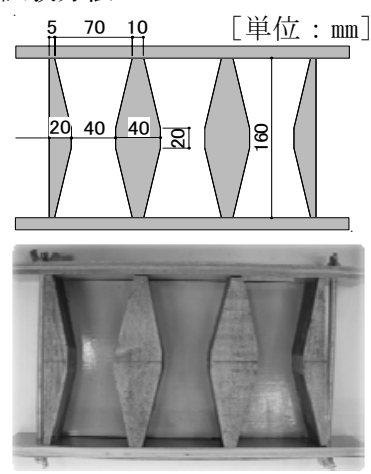

図 4 引張強さ試験用型枠
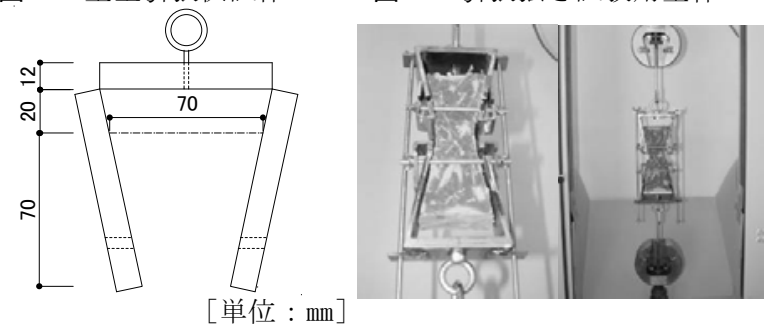

図 5 引張用治具

写真 3 実験風景

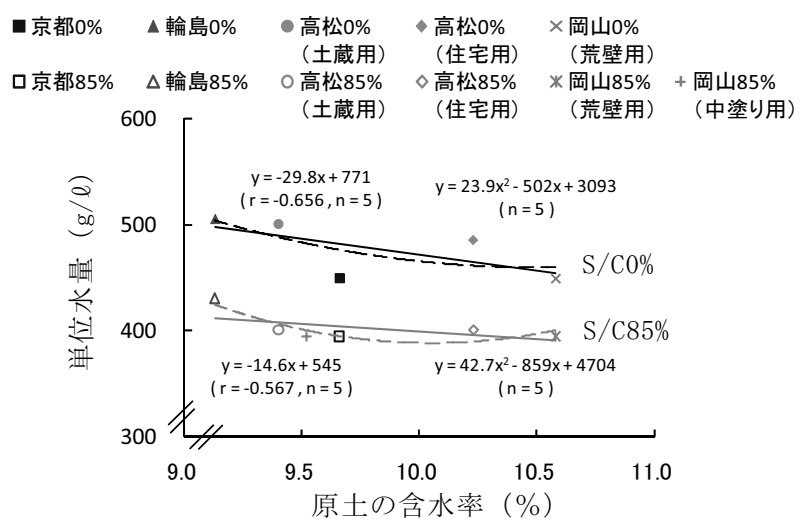

図 6 原土の含水率と単位水量の関係（実験 2 ) 


\section{3) 原土別の粒度分布（図 7 図 8)}

壁土用原土は実際の土質・地盤よりも粒径幅が極めて狭い範囲 であるが、京都、豊田および岡山産土（荒壁および中塗り用）は 粘土、シルトおよび細砂まで分布する、締固め特性の良い粒径幅 の広い土と言える。一方、輪島および高松産土（土蔵および住宅 用）は、粒径 $50 \mu \mathrm{m}$ 以下の傾きが急で両者はほぼ平行し、締固め 特性の悪い分級された土である。締固め特性の良い、悪いは土盛 りなど地盤の安定性についての表現で、土壁の塗りやすさと意味 が異なるが、原土の粒径幅は大略 1～200 $\mu \mathrm{m}$ に集中している。

原土について、手ふるいの限界に近い粒径 $75 \mu \mathrm{m}$ でみると積算 值 $80 \%$ 以上、平均粒径（50\%粒径） $20 \mu \mathrm{m}$ 前後である。特に輪島 産土は薄くハンドクリームで覆われたような感覚が得られた。ま た、高松産土の土蔵および住宅用の場合、前者は後者より微粒子 の含有率が高く粘りがあることを表している。実際、レディーミ クスト壁土製造者は経験的に土蔵用と住宅用を明確に分けて販売 していることからも、適材適所の粒度分布が存在することを示し ている。基準の京都産土は粒径 $75 \mu \mathrm{m}$ でみると、凡そ積算值 $80 \%$ 、 平均粒径 $20 \mu \mathrm{m}$ であるが、手ふるいの場合 $20 \% 、 250 \mu \mathrm{m}$ を与え機 械との違いが認められた。

図 7 京都産土（-口）を基準に考えると、曲線が左側に移動す れば原土は粘りがあり、微粒子の含有率によって曲線勾配および 粘りの強さが変化する。前述したように、中でも輪島産土は粒径 幅の範囲が狭く締固め特性の悪い土であるが、実際の土塗り現場 では粘りが強いため砂を加え調節している。一方、右側にある曲 線は岡山産土（荒壁および中塗り用）のように粒径幅が広い範囲 にわたって分布し、締固め特性の良い土のため粘りはなく鏝仕上 げが容易である。参考までに、粒径 $75 \mu \mathrm{m}$ 以下の積算值と実施調合 した実験 2 ）の単位水量の関係は、荒壁土の場合、S/C に関らず $\mathrm{r}=0.7$ 以上と高く、微粒分を多く含む原土ほど練混ぜ時に多量 の水が必要なことを表している。

以上のことから、壁土用原土の性質はレーザー回折の積算值 （粒径加積曲線）からある程度推察され、締固め特性の悪い土で 平均粒径 $25 \mu \mathrm{m}$ 以下が多い。

\section{4 ）フロー値と密度（図9）}

基本調合（実験 1 ）のフロー值は、原土に関わらず $\mathrm{S} / \mathrm{C}$ の増加 に伴い大きくなる。しかし、輪島および高松産土（土蔵および住 宅用）は、目標フロー值 $135 \pm 10$ が得られなかったことから、試 し練り（実験 2 ) した。

実験 1 ) では、S/C に関係なく輪島産土の場合フロー值が低く、 締め固めるようにして供試体を作製した。しかし、実際の土塗り の場合、鏝離れが悪く労力も必要になるため作業性が期待できず、 筆者らの求めた目標フロー值 $\left.135 \pm 10^{10)} 11\right)$ は適切で、原土に合っ た実施調合は基本調合を用いるよりもワーカビリチーの良いこと を確認した。このことは、粘りがあれば、砂を加え、作業のしや すいコンシステンシーを得ることが壁土の品質確保できることを 示唆している。したがって、既存建物の土壁ではほとんどが砂を 加えていると考えられるため、品質に問題ないと言える。

フロー值と密度の関係は、基本調合の締め固めた壁土と実施調 合したものとほとんど差がなく一次式はほぼ横ばいである。この ことは、一定のコンシステンシーを得ていれば、密度は塗り層の

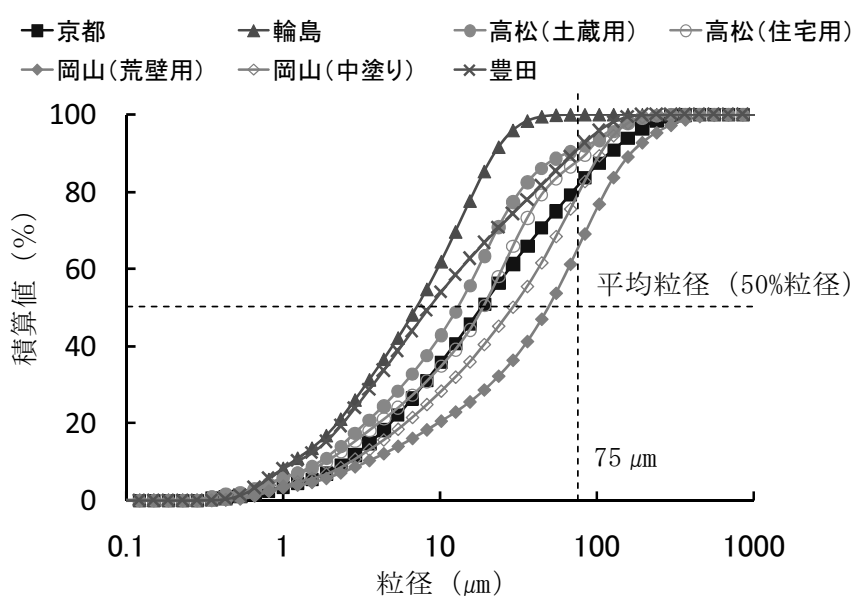

図 7 原土別の積算値（粒径加積曲線）

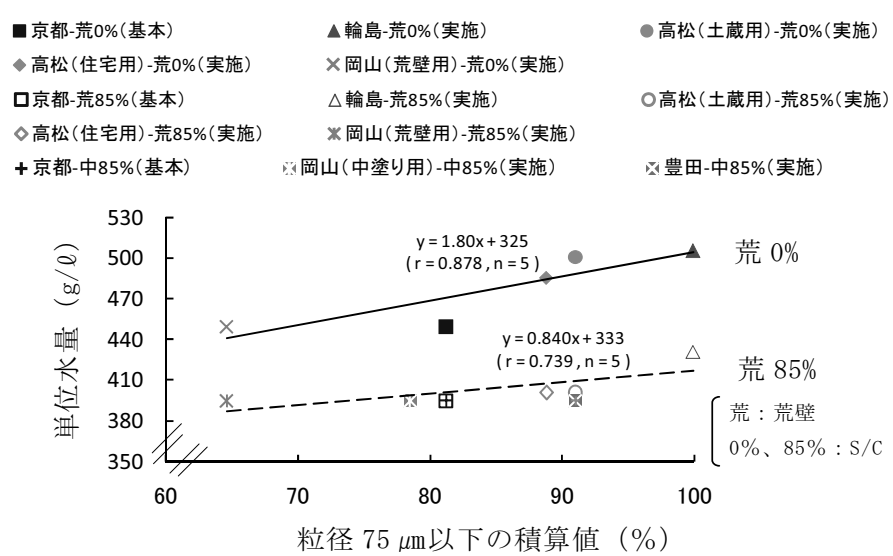

図 8 粒径 $75 \mu \mathrm{m}$ 以下の積算值と単位水量（実験 2 ）の関係

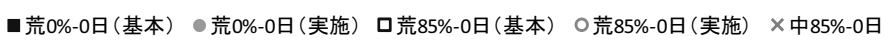

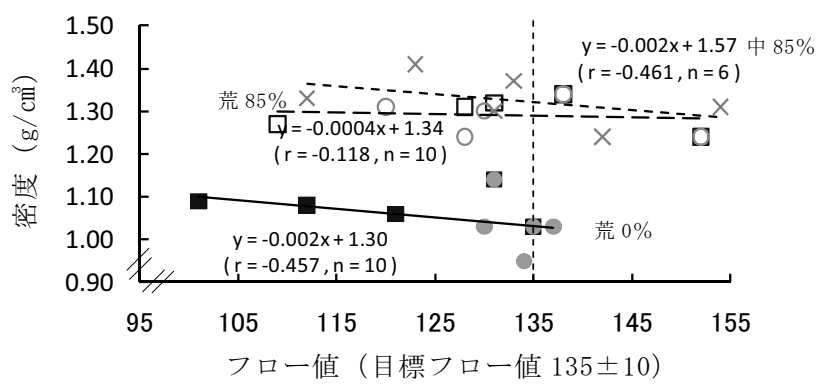

図 9 フロー值と密度の関係

違いはあるが、フロー值による影響をほとんど受けないことを表 している。

\section{5 ）吸放湿量変化率（図 10、写真 1)}

最大吸放湿量変化率は、荒壁土の調合別でみると原土の種類お よび $\mathrm{S} / \mathrm{C}$ に関わらず吸湿で基本調合＜実施調合、放湿は基本調合 >実施調合となる。S/C $85 \%$ でみると、豊田産土を除く基本調合 で作製した 5 種の中塗り土は、原土の種類に関わらず荒壁土に比 べ吸湿で上回るが、放湿で劣るのは糸状と管状のスサの違いも一 因と推察する。原土別にみると、輪島産土の吸放湿は優れている が、粒径幅が広く締固め特性の良い岡山および豊田産土は劣る。

日干レレンガは吸湿の場合、輪島産土 S/C 85\%（3.1\%）の 1.2 倍であるが、放湿は負 $($ - 值にならない。これは、直径 $2 \mathrm{~cm}$ 程度 の碩を多く含んでいることや供試体寸法の違いも一因と考える。 


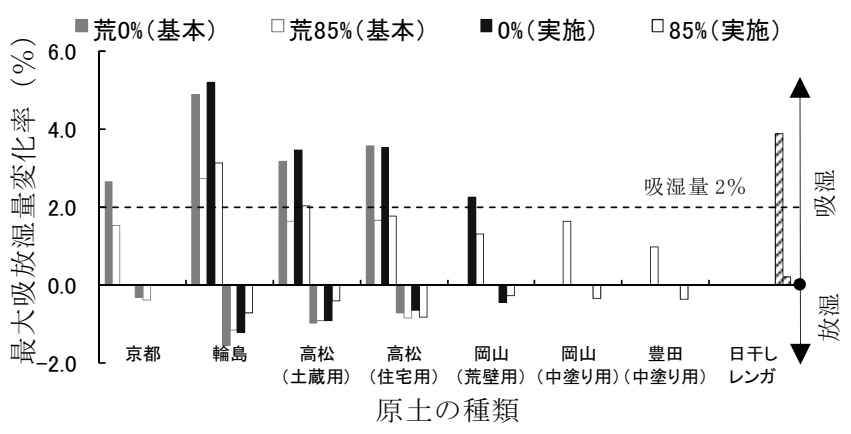

図 10 試料別の吸放湿量変化率

6 ）曲げ、圧縮、せん断および引張強さ（図 11〜図 12、写真 1 )

曲げ強さは、荒壁土の場合、原土および調合の違いによる差は ほとんど認められないが S/C 0\%が 85\%を上回る。

圧縮、せん断および引張強さは、荒壁土の調合別でみると、原 土の種類に関わらず $\mathrm{S} / \mathrm{C} 0 \%$ で基本調合＞実施調合、85\%は基本調 合 <実施調合となる。個々の強さは水合せ 0 日 $>$ 水合せ 7 日、S/C $0 \%>S / C$ 8 $\%$ を得るが、水合せについては原土の違いによる差異 はない。また、ほとんどの原土は、文献 14）の圧縮強さ荒壁 0.3 $\mathrm{N} / \mathrm{mm}^{2}$ 以上、中塗り $0.55 \mathrm{~N} / \mathrm{mm}^{2}$ 以上を満足する。

壁土の個々の強さは S/C の違いによる差は認められないが、基 本調合の曲げ強さ 1 に対して圧縮、せん断および引張強さを安全 側に取ると、それぞれ $2.0 、 0.5$ および 0.5 倍で、実施調合でも同 じ值が得られる。一方、日干しレンガの応力ーひずみ曲線はよう かんに比べて立ち上がり勾配が急で、ひずみ 0.05 前後から周囲の 圧壊が僅かずつ始まるが、線形的に延び続ける。また、最大応力 のひずみはようかんの場合、S/C 0 および $85 \%$ で異なり、大略 0.10 および 0.05 を与える。しかし、日干しレンガは供試体周囲が圧壊 で僅かずつ崩落するが、中心部が残り木材の年輪方向の載荷と同 様に応力が増加し続ける ${ }^{15)}$ ため、ひずみ 0.09 で強制的に試験を 終了した。その時の圧縮強さは $2.5 \mathrm{~N} / \mathrm{m}$ 前前後でようかんの 3.0 倍 以上となるが、ひずみ 0.05 では $1.4 \mathrm{~N} / \mathrm{mm}^{2}$ 程度を与える。また、 キャッピングしない載荷面の不陸な状態の圧縮強度が $2.0 \mathrm{~N} / \mathrm{m} \mathrm{m}^{2}$ 以 上を示すことから安全側に取り日干しれんがの強度と看做した。

文献 3 ）の土蔵修復材は、輪島産土の荒壁土 S/C 85\% とス混 入率に多少の差はあるが、圧縮強さは $0.7 \mathrm{~N} / \mathrm{mm}^{2}$ 前後とほぼ一致し た值が得られ、切り出し ${ }^{3)}$ とようかんでは大差なく、既存建物の 土壁をようかんで評価しても問題ないと考える。また、文献 5 ) の豊田産土（中塗り用）を用いた $\phi 50 \times 100 \mathrm{~mm}$ 供試体を機械乾燥 した圧縮強さはようかんと同程度の $1.0 \mathrm{~N} / \mathrm{mm}^{2}$ を示し、供試体形状 が異なっても差異がない。したがって、養生方法についても、促 進（機械）乾燥と自然乾燥では大差ないと言える。

以上のことから、各々の強さは $\mathrm{S} / \mathrm{C}$ および調合方法によって異 なることを明らかにした。しかし、実際の土塗りでは原土に砂を 加えない（S/C 0\%）ことは稀にあるが、砂を加える（S/C 85\%） のが一般的である ${ }^{16)}$ 。したがって、今回の結果はその地域の原土 に砂、あるいは原土を加えコンシステンシーを一定にした壁土で あれば、所要の強さを満足することを示唆している。

土壁は、同じ原土を用いた場合、既存建物で砂を混入していれば、 ある程度の強さを確保していることを確認した。しかし、実際の 建物は実験室と環境が異なり、外部から風雨・凍結等の影響を受
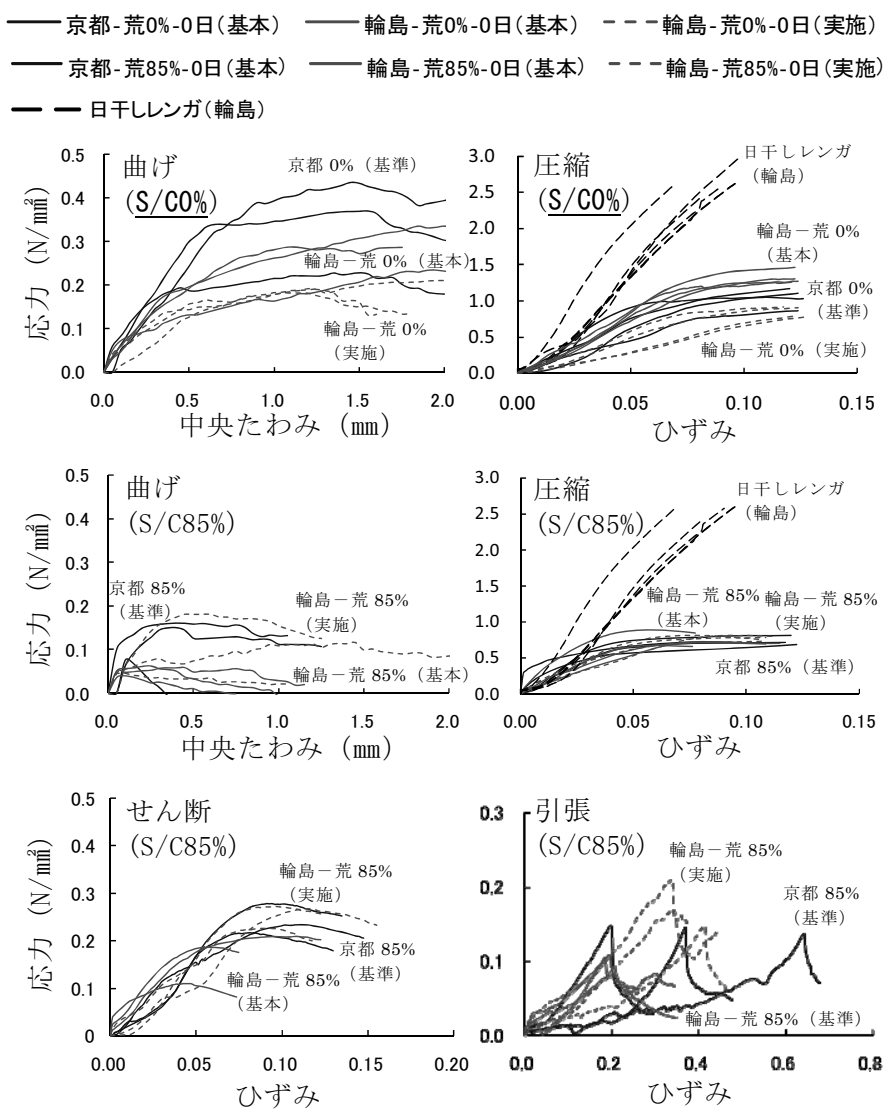

図 11 原土別の応力一たわみ曲線、応力一ひずみ曲線（例）
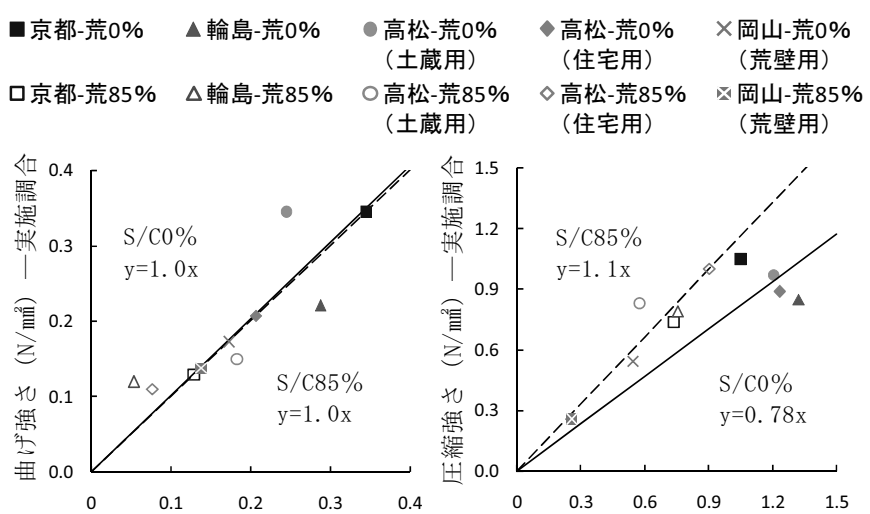

曲げ強さ $\left(\mathrm{N} / \mathrm{mmin}^{2}\right)$ 一基本調合
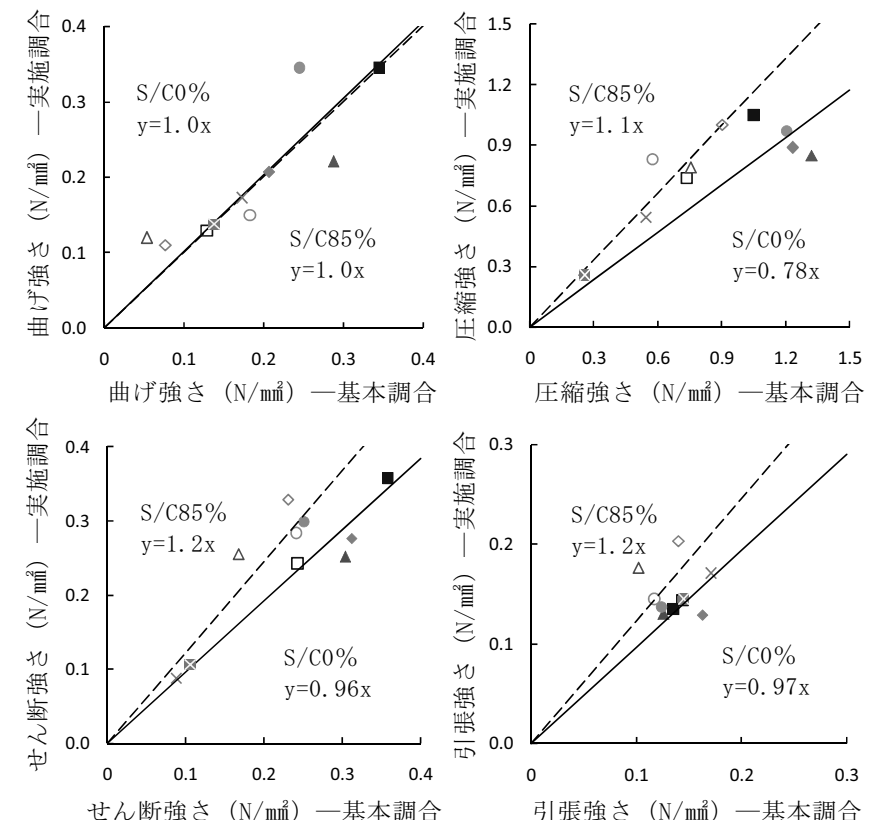

圧縮強さ $\left(\mathrm{N} / \mathrm{mm}^{2}\right)$ 一基本調合

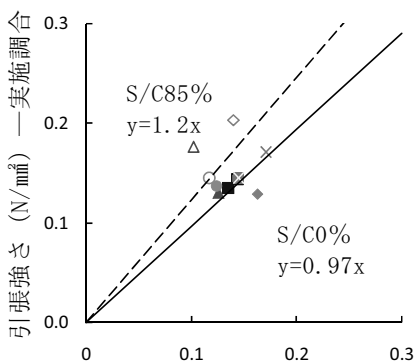

胎さ $\left(\mathrm{N} / \mathrm{mm}^{2}\right)$ 一基本調合

図 12 各強さにおける基本調合（実験 1 ）と実施調合（実験 2 ） の関係

けるため、土塗り壁の表面から剥落して劣化することは明らかで ある。 


\section{5. まとめ}

地域産の壁土用原土の数は少ないが、基本調合および実施調合 した壁土の性質を要約すると次の通りである。

1 ）壁土用原土は締固め特性の悪い土で、粒径 $75 \mu \mathrm{m}$ でみると積 算值 $80 \%$ 以上、平均粒径 $25 \mu \mathrm{m}$ 前後の多いことがレーザー回折 から示される。

2 ）基本調合で締固めた壁土は、実際の土付けの場合、鏝離れが 悪く労力も必要になるため作業性を期待できないが、フロー值 $135 \pm 10$ がワーカビリチーの適切なことを確認した。

3 ）吸放湿性能は、吸湿の場合、基本調合<実施調合、放湿は基 本調合 >実施調合となる。日干しレンガは碩を多く含むことか ら、放湿性能は負 $(-)$ 值にならない。

4 ) 実施調合の壁土は、基本調合よりも強さなどの品質が上回る。 ようかんの個々の強さは調合に関わりなく、曲げ強さ 1 に対し て圧縮、せん断および引張強さを安全側に取ると、それぞれ大 略 2.0、0.5 および 0.5 倍を与える。日干しレンガの圧縮強さ は $2.0 \mathrm{~N} / \mathrm{mm}^{2}$ を回り、ようかんの 2 倍以上となる。

以上のように、壁土用原土の採取地域が異なっても、その地域 の原土に合った実施調合、すなわち、砂を加えたコンシステンシ 一一定の壁土は性質が向上する。同一試験法の適用は、既存建物 での土壁の評価を可能にし、安全あるいは安心を確認できること から、新たな工法・構法への発展と改善につながる。また、レー ザー回折による粒度分布の積算值（\%）は、手ふるいの粒径加積 曲線の通過質量百分率（\%）と一致することから原土の特性を簡 易に評価する有効な手段であることを示唆している。

\section{謝辞}

試料提供の山田耕司（豊田工業高等専門学校）・萩野紀一郎（輪 島市: 萩野アトリエ)、議論して頂いた土壁研究会の方々に感謝し ます。また、平成 21 年度工学設計 III 受講者の協力に謝意を表しま す。

\section{参考文献}

1)岩崎ほか：福島県産壁土の工法仕様標準化に関する研究（その1）－熟 練左官技能士による壁土調合の標準化一, 日本建築学会大会学術講演梗 概集，A-1，pp. 1067-1068，1996 [一連の研究]

2) 興石ほか：主要産出地における荒壁土および中塗土の性質 小舞土壁に 用いる壁土に関する研究 その 1 ，日本建築学会構造系論文集，第 631 号, pp. 1467-1474, 2008.9

3) 興石ほか：能登輪島の土蔵およびその修復に用いられた壁土の性質, 日 本建築学会技術報告集，第 30 号, pp. 377-382, 2009.6

4) 中尾ほか：土塗り壁の耐力および変形性能の推定に関する実験的研究 (その 11 各地の壁土の強度の変動幅について), 日本建築学会大会学 術講演梗概集 (中国)，C-1，pp. 489-490，2008.9

5)山田ほか：壁土材料試験体の定温乾燥機による乾燥, 日本建築学会大会 学術講演梗概集（東北），A-1，pp. 459-460，2009.8

6) 三芳ほか：土壁の強度に関する研究, 日本建築学会大会学術講演梗概集

(北陸), C-1, pp. 207-208, 2002.8

7) 三芳ほか：土壁の強度に関する研究 その 2 実大面内せん断試験, 日 本建築学会大会学術講演梗概集 (東海)， C-1, pp. 409-410, 2003.9 8) 濱﨑ほか：土壁の強度に関する研究 その 3 壁土圧縮試験, 日本建築
学会大会学術講演梗概集 (北海道)， C-1，pp. 399-400，2004. 8

9) 例えば，鈴木ほか：木造住宅土塗り壁の実大実験による耐震性能の再検 討, 日本建築学会構造系論文集, 第 515 号, pp. 115-122, 1999.1, 山 田ほか：土塗り小舞付き木造軸組耐力特性評価への数值解析の適用, 日 本建築学会構造系論文集, 第 621 号, pp. 81-87, 2007. 11

10）浦ほか：壁土の供試体作製及び強度試験法に関寸る基礎実験，日本建 築学会構造系論文集, 第 559 号, pp. 23-30, 2002.9

11）浦ほか: 壁土の試験方法に関する基礎実験, 日本建築学会技術報告集, 第 24 号, pp. $35-38,2006.12$

12）萩野紀一郎：実例にみる既存木造住宅の耐震改修 土蔵の耐震改修／ 輪島，建築技術，第 697 号，pp. 158-161，2008. 2

13）浦ほか：壁土の品質に関する基礎実験 その 3 壁土の引張強さ, 日 本建築学会大会学術講演梗概集 (中国)， A-1, pp. 179-180, 2008.9

14）土塗壁告示に係る技術解説書作成委員会：土塗壁・面格子壁・落とし 込夕板壁の壁倍率に係る技術解説書, pp. 19-30, 日本住宅・木材技術 センター，2004. 2

15）伏谷賢美 : 木材の科学・ 2 木材の物理，文永堂，pp. 141-142，1985.9

16）日本建築学会：建築工事標準仕様書 - 同解説 JASS15 左官工事, 日 本建築学会, pp. 279-282, 2007.6

17)浦 憲親：土壁の性質に関する基礎実験-日干しれんが-, 日本建築学 会北陸支部研究報告集, 第 53 号, pp. 7-8, 2010.7

18) 河原ほか：金沢市における伝統木造建物の耐震性能評価に関する研究, 日本建築学会大会学術講演梗概集 (中国)， C-1, pp. 491-492, 2008.9

19)河原ほか：金沢市域における伝統木造建物の耐震性能，日本建築学会 大会学術講演梗概集 (東北)， C-1, pp. 255-256, 2009.8

[2010 年 9 月 8 日原稿受理 2010 年 12 月 7 日採用決定］ 